\title{
Study of biosocial factors affecting laparoscopic tubal ligation in rural Maharashtra, India
}

\author{
Swati N. Nagapurkar ${ }^{1 *}$, Anjanadevi S. Santpure ${ }^{1}$, Purushottam A. Giri², Prasad L. Bhanap ${ }^{1}$ \\ ${ }^{1}$ Department of Obstetrics and Gynecology, Indian Institute of Medical Science and Research Medical College, \\ Badnapur, Jalna, Maharashtra, India \\ ${ }^{2}$ Department of Community Medicine, Indian Institute of Medical Science and Research Medical College,, Badnapur, \\ Jalna, Maharashtra, India
}

Received: 22 October 2016

Accepted: 15 November 2016

\section{*Correspondence:}

Dr. Swati N. Nagapurkar,

E-mail:67swati@gmail.com

Copyright: (C) the author(s), publisher and licensee Medip Academy. This is an open-access article distributed under the terms of the Creative Commons Attribution Non-Commercial License, which permits unrestricted non-commercial use, distribution, and reproduction in any medium, provided the original work is properly cited.

\begin{abstract}
Background: As compared to vasectomy, Indian women prefer female sterilization as the best mode sterilization. Many socio-demographic factors and gender of living children affects women in deciding laparoscopic tubal ligation. Objective of the study was to assess the biosocial factors affecting of laparoscopic tubal ligation patients in rural area and also to asses average family size and preference for male child before laparoscopic tubal ligation.

Methods: A cross-sectional study was done during January to June 2016 in Indian Institute of Medical Science and Research medical College, Badnapur, Jalna, Maharashtra. A total of 549 patients from rural area, underwent laparoscopic tubal ligation were enrolled for the study. Data was analyzed by using percentage and proportion whenever necessary.

Results: In this study, mean age of patients undergoing tubal ligation was $26.37 \pm 3.82$ year. Maximum patients were from 25-29 years age group and among them $45.54 \%$ were illiterates. Average family size was $2.61 \pm 0.66$. In $51.73 \%$ cases, couple themselves motivated for their sterilization. Education of both participant and their husband was significantly related to the total no. of living children. Only 9 patients under went tubal ligation with only 1 male child, while all other couples had at least one male child in the family.

Conclusions: The study reveals that all couple had at least one male child. Education of both participant and their husband was an important factor in deciding the size of family.
\end{abstract}

Keywords: Biosocial factors, Laparoscopic tubal ligation, Rural India

\section{INTRODUCTION}

Family planning allows couple to anticipate and attain there desired no. of children. India is the second most populated developing country in word. ${ }^{1}$ The population was 1.23 billion people comprising 624 million males and 587 million females. India will become most populous country by 2025 and surpasses China by 2050 . $^{2}$ The availability of resources will be depleted if the population rises continuously leading to poverty, environmental degradation etc. ${ }^{3}$ Hence population control is essential by controlling the reproduction, so that the quality of life of people will be improved. Increased uses of contraceptive have been reported in many parts of world mainly in Asia. Government of India has been taking various steps to overcome this problem of population. India was the first nation to formulate a National Family Program in Year 1952, As the population was grown from 361 millions in 1951 to 844 millions in 1991. ${ }^{4}$ After implementation of family planning there was declining crude birth rate from 44 per 1000 population in 1951 to 30 in 1991 . The crude birth 
rate is $19.89 \%$, death rate is $7.35 \%$, and population growth rate was $1.25 \%$. The population policy of Indian Government is implementing family planning and contraceptive service delivery. ${ }^{4}$ Later Government recognized the link between population and development, so introduced small family norm and incentives to accepters and motivators. In 2005, Government introduced National Rural Health Mission (NRHM) for uniform implementation of services. ${ }^{5}$ Family planning services are temporary methods for spacing of birth as well as limiting births. Knowing the fact that increased no. of male sterilization would provide a great hand in family planning, though it is not popular in any part of country. Two important reasons for this are the dominance of male in decision making of family planning and the social stigma in women which they will faced if there is failure of male sterilization and ending up in pregnancy. It would take many decades to bring this awareness in people. This has made tubal ligation as a permanent method of sterilization either mini laprotomy or laparoscopic sterilization. The complication rates with tubal ligation done with laparoscope are 2.1/100 and with mini laprotomy is $6.2 / 100 .^{6}$ There are many hindrances mainly in rural area. Various studies are done in rural areas to know various causes influencing tubal ligation in women but the factor differ from region to region. So this present study was undertaken to know the factors influencing tubal ligation in various villages in the area of Badnapur, Jalna, Maharashtra, India.

\section{METHODS}

A cross-sectional study was undertaken from January 2016 to June 2016 in a Tertiary Care Center JIIU'S Indian Institute of Medical Science and Reasearch Medical College, Badnapur, Jalna, Maharashtra, India. A total of 549 women got admitted during the study period from various villages of Maharashtra and willing for laparoscopic tubal ligation in the Department of Obstretic and Gyanecology constituted the sample study. Detailed information on socio-demographic profile, no. of children, motivators, education status of couple was taken after admission in the ward. The patients were mobilized by the social workers from various villages. This information was used to understand the factors influencing laparoscopic sterilization. All the patients after anesthetic fitness underwent laparoscopic tubal ligation under sedation with local anesthesia.

\section{Statistical analysis}

The data was entered in MS Excel sheet and results were analyzed statistically using percentages, proportions and the chi-square test. Statistical significance was set at $\mathrm{p}<0.05$.

\section{RESULTS}

It was seen from Table 1 that the most common age group of the patients in the study belongs to the age group of 25-29 years constituting $55.74 \%$ followed by 20-24 years which constituted $30.60 \%$. Mean age of participant was $26.37 \pm 3.82$ years. It was observed that $50.27 \%$ of the participants had at least 2 children and $37.16 \%$ had three children. Mean number of children in the family was $2.61 \pm 0.66$. Majority $(80.33 \%)$ of the woman belongs to the Hindu and $10.38 \%$ were Muslim by religion. It was observed that $61.20 \%$ of participants belong to joint family and $38.80 \%$ to nuclear family. It is seen $45.54 \%$ of the patients were illiterate and only $3.83 \%$ were educated up to higher secondary. On the contrary, only $18.21 \%$ of husbands were illiterate and $16.03 \%$ were educated up to higher secondary. $28.60 \%$ of the participants belong to lower class socio economic status.

Table 1: Biosocial characteristics of the study population.

\begin{tabular}{|c|c|c|}
\hline $\begin{array}{l}\text { Biosocial } \\
\text { characteristics }\end{array}$ & $\begin{array}{l}\text { Frequency } \\
(n=549)\end{array}$ & Percentage \\
\hline \multicolumn{3}{|l|}{ Age in years } \\
\hline $20-24$ & 168 & 30.60 \\
\hline $25-29$ & 306 & 55.74 \\
\hline $30-34$ & 60 & 10.93 \\
\hline$\geq 35$ & 15 & 2.73 \\
\hline \multicolumn{3}{|l|}{ No. of living children } \\
\hline 1 & 9 & 1.64 \\
\hline 2 & 276 & 50.27 \\
\hline 3 & 204 & 37.16 \\
\hline 4 & 45 & 8.20 \\
\hline 5 or more & 15 & 2.73 \\
\hline \multicolumn{3}{|l|}{ Religion } \\
\hline Hindu & 441 & 80.33 \\
\hline Muslim & 57 & 10.38 \\
\hline Others & 51 & 9.29 \\
\hline \multicolumn{3}{|l|}{ Type of Family } \\
\hline Joint family & 336 & 61.20 \\
\hline Nuclear Family & 213 & 38.80 \\
\hline \multicolumn{3}{|c|}{ Education of Participant } \\
\hline Illiterate & 250 & 45.54 \\
\hline Primary & 105 & 19.13 \\
\hline Secondary & 173 & 31.51 \\
\hline Higher Secondary & 21 & 3.83 \\
\hline Graduate & 0 & 0.00 \\
\hline \multicolumn{3}{|c|}{ Education of Participant's Husband } \\
\hline Illiterate & 100 & 18.21 \\
\hline Primary & 85 & 15.48 \\
\hline Secondary & 235 & 42.81 \\
\hline Higher Secondary & 88 & 16.03 \\
\hline Graduate & 41 & 7.47 \\
\hline \multicolumn{3}{|c|}{ Socio-Economic Status } \\
\hline Lower Middle class & 176 & 32.06 \\
\hline Upper lower class & 216 & 39.34 \\
\hline Lower Class & 157 & 28.60 \\
\hline
\end{tabular}


It was seen from Table 2 that motivation and decision to undergo tubal ligation was by couple in $51.73 \%$ followed by $20.04 \%$ by husband. Self decision was taken in $7.65 \%$ of the cases. Mother in law motivated in $16.94 \%$ of the patients.

Table 2: Distribution of motivators for laparoscopic tubal ligation.

\begin{tabular}{|lll|}
$\begin{array}{l}\text { Motivation done } \\
\text { by }\end{array}$ & $\begin{array}{l}\text { No. of patients } \\
(\mathbf{n = 5 4 9 )}\end{array}$ & $\begin{array}{l}\text { Percentage } \\
\text { Self }\end{array}$ \\
\hline Husband & 110 & 7.65 \\
\hline Couple & 284 & 20.04 \\
\hline Mother in Law & 93 & 51.73 \\
\hline
\end{tabular}

Table 3: Correlation of education of patients and no. of living children.

\begin{tabular}{|llllll|}
\hline Education & $\leq 2$ children $(n=290)$ & $\geq 2$ children $(n=259)$ & Total $(n=549)$ & Percentage & p-value \\
\hline Illiterate & 100 & 150 & 250 & 45.54 & $X^{2}=30.9265$ \\
\cline { 8 - 8 } & 65 & 40 & 105 & 19.13 & P $<0.0000$ \\
Secondary & 110 & 63 & 173 & 31.51 & Highly significant \\
\hline Higher Secondary & 15 & 6 & 21 & 3.83 & H \\
\hline
\end{tabular}

Table 4: Correlation of education of husband with no. of living children.

\begin{tabular}{|c|c|c|c|c|c|}
\hline Education & $\leq 2$ children $(n=298)$ & $\geq 2$ children $(n=251)$ & Total $(n=549)$ & Percentage & P-value \\
\hline Illiterate & 35 & 65 & 100 & 18.21 & \multirow{5}{*}{$\begin{array}{l}X^{2}=38.6024 \\
P<0.0000 \\
\text { Highly significant }\end{array}$} \\
\hline Primary & 35 & 50 & 85 & 15.48 & \\
\hline Secondary & 135 & 100 & 235 & 42.81 & \\
\hline Higher Secondary & 62 & 26 & 88 & 16.03 & \\
\hline Graduate & 31 & 10 & 41 & 7.47 & \\
\hline
\end{tabular}

Table 5: Distribution of male and female children amongst study population.

\begin{tabular}{|llll|}
\hline $\begin{array}{l}\text { No. of } \\
\text { male } \\
\text { children }\end{array}$ & $\begin{array}{l}\text { No. of } \\
\text { female } \\
\text { children }\end{array}$ & $\begin{array}{l}\text { No. of } \\
\text { patients } \\
(\mathbf{n = 5 4 9})\end{array}$ & Percentage \\
\hline 1 & 0 & 9 & 1.63 \\
\hline 0 & 1 or 2 & 0 & 0.00 \\
\hline 1 & 1 & 207 & 37.70 \\
\hline 2 & 0 & 69 & 12.56 \\
\hline 2 & 1 & 48 & 8.74 \\
\hline 1 & 2 & 156 & 28.41 \\
\hline$\geq 2$ & $\geq 2$ & 60 & 10.92 \\
\hline
\end{tabular}

\section{DISCUSSION}

Female sterilization is most common method of contraception in India. As per DLHS-IV (2012-13) Maharashtra State follows $59.4 \%$ as female sterilization compared to $1.4 \%$ as male sterilization in rural area. ${ }^{7}$

In our study, $55.7 \%$ of patients were from age group of 25-29 years comparable to the study in which $44.3 \%$ in Vaishav et al and $58.9 \%$ in study by Prayag et al and $56 \%$ were in the age group of 30-35 years in study done by Puwar B et al. ${ }^{8-10}$ Mean age of patients was $26.37 \pm 3.82$ years comparable to the study of 24.14 years by Palli et al and 25.9 \pm 2.89 years in Prayag et al. ${ }^{8,11}$ This shows that Indian rural woman get married at a mean age of at 19.3 years and choose permanent method of contraception at younger age. $^{7}$

In our study, $80.33 \%$ were Hindus comparable to the study of Puwar B et al. ${ }^{10}$ As per their religious reason Muslim community do not prefer sterilization as they think it is a sin.

Our study revealed that $61.2 \%$ were from Joint family indicating in the involvement of family members in favoring permanent method of sterilization as study by Prayag et al which showed elders in the family motivated in $40.7 \%$ of patients for permanent sterilization. ${ }^{9}$

Our study revealed that $45.5 \%$ of patients were illiterate and $3.8 \%$ were studied upto higher secondary which was comparable to study by Puwar B et al which showed $45 \%$ illiterate and 5\% upto higher secondary respectively and study by Athavale AV et al which mentioned $23 \%$ were 
illiterate and $66 \%$ were educated beyond primary. ${ }^{10,12}$ Contrast to the patient's education, only $18.21 \%$ of husbands were illiterate and $42.8 \%$ were educated up to higher secondary school as comparable to study done by Puwar B et al. ${ }^{10}$

Our study showed $67.94 \%$ belonged to lower and upper lower class comparable to the study by Puwar B et al which showed $77 \%$ were daily wage workers and $81 \%$ belongs to below poverty line study by Prayag et al. ${ }^{9,10}$

On contrast to the study by Rajendra Singh et al showing $85 \%$ having three children and our study showed $50.27 \%$ were having two living children. ${ }^{13}$ Only $2.7 \%$ had more than four children comparable to $52.5 \%$ and $3.5 \%$ in Prayag et al study and $52.2 \%$ and $4.14 \%$ in Vaishnav et al study respectively. ${ }^{8,9}$

Motivating woman to undergo tubal ligation was influenced by family members, health personals, traditions and customs. In our study, $51.7 \%$ of the patient who underwent laparoscopic tubal ligation was motivated by couple themselves and $16.9 \%$ by her mother in law which was comparable to study by Pryag et al, which showed $49.4 \%$ were motivated by couple themselves. ${ }^{9}$

Thakur $\mathrm{N}$ et al study also demonstrates that demographers and programme managers have also found that involvement of couple is necessary than the individual involvement of women or men in achieving the goal. ${ }^{14}$ In contrast to our study a study by Geethan Lakshmi et al showed husband decided the sterilization in majority of the patients. ${ }^{15}$

In our study, we observed that education of the patient and their husband was significantly associated with the total no. of living children indicating education place important factor in population control. These results were similar to a study done by Prayag et al. ${ }^{9}$

Son preference in India is a well-documented phenomenon and its implication leads difference sex ratio and female feticide. International center for research on woman (ICRW) analyzed a rural sample of 50136 ever married woman and their surviving children younger than 5 years from a national family health survey in 19921993 concluded that mothers gender preference for son for their complete family composition. ${ }^{16}$ Our study also showed that all the patients had at least one male child before tubal ligation. Majority of patients had one girl and one male child. Study by Puwar B et al showed $97.24 \%$ had one or more male child. ${ }^{10}$ Study by Abhishek Singh et al suggests that woman who had only daughters were more likely to regret than woman who had only sons after undergoing sterilization. So many women procreate many children for a male child. ${ }^{17}$

\section{CONCLUSION}

A couple educations are the significant factor in increasing tubal ligation. Mother's education along with the family support is the significant factor in reducing the son preference and increasing the tubal ligation after an average family size. Mass media and health education plays role in spreading the knowledge, awareness of the safety, easiness of surgical procedure and removing myths to enhance vasectomy.

\section{ACKNOWLEDGEMENT}

We express our deep sense of gratitude to the Management, JIIU Trust and Dr. Amarnath B. Solepure, Dean, IIMSR Medical College, Badnapur, Jalna, Maharashtra. We also acknowledge the help and support of Dr. A. M. Khadri, Medical Superitendent, Noor Hospitial, Badnapur, Jalna, Maharashtra.

Funding: No funding sources

Conflict of interest: None declared

Ethical approval: The study was approved by the Institutional Ethics Committee

\section{REFERENCES}

1. 2011 census data. Available from: http:// censusindia.gov.in/2011census/population_enumerat ion.html. (Last accessed on 10th Sept. 2016).

2. Demographics of India. Available from http:// en.wikipedia.org /wiki /Demographics_of_India. (Last accessed on 19th Sept. 2016).

3. Human population control Wikipedia. Available from: http: // en/ Wikipedia.org / wiki / Human _ population _ control. (Last accessed on 25th Sept. 2016).

4. Desai S. Gender Inequalities and Demographic Behaviour India. The Population Council/New York 1994. Available from: www.Sonaldedesai. org/desai_1994_gender_ineqalit.pdf. (Last accessed on 20th Sept. 2016).

5. International Institute of Population Sciences District Level Household and facility Survey 2007-2008 (DLHS-3) April 2010 Ministry of Health and Family Welfare. 2000;46(2).

6. Smith GL, Taylor GP, Smith KF. Comparative risks and costs of male and female sterilization. Am J Public Health. 1985;75(4):370-74.

7. District Level Household and Facility Survey (DLHS-4), 2012-2013 fact sheet Maharashtra. International Institute for Population Sciences Deonar, Mumbai. Ministry of health and family welfare, Government of India. 2012-13. Available from: www.rchiips.org/ pdf/ dlhs4/ report/ MH.pdf. (Last Accessed 15th Sept. 2015).

8. Vaishnav G, Jolly V, Divyesh P. Prospective Study of the Single Puncture Laparoscopic Tubal Ligation. Natl J Medical Research. 2011;1(2):42-4. 
9. Prayag A, Ashtagi GS, Patil SK, Mallapur MD. Factors Influencing Tubectomy among Women of Rural Belgaum: A Cross-Sectional Study. International Journal of Scientific Research. 2015;4(5):645-47.

10. Puwar B, Patel V, Patel M. Factors Affecting Sterilization Operation among Couples of a Rural Area in Ahmedabad: A Record-Based Study. Indian Journal of Medical Sciences. 2012;66(11):267-72.

11. Palli SB, Akkupalli VL. A comparative study on complications of double puncture laparoscopic sterilization and conventional tubal ligation methods. Int J Med Biosci. 2013;2(1):1-8.

12. Athavale AV, Athavale SA. Factors influencing the decision to undergo tubectomy in rural area of Maharashtra Regional Health: Forum WHO South East Asia Region. 2003;7:42-7.

13. Singh R. Laparoscopic female sterilization by single port through monitor a better alternative. J Indian Medical Assosci. 2011;109:262-66.

14. Prajapati TN, Nayak D, Chauhan SJ. A crosssectional study on gender bias in fertility and family planning choices in a rural area of Patan district of Gujrat, India. International Journal of Interdisciplinary and Multidisciplinary Studies. 2014;1(7):77-84.

15. Lakshmi G, Chandrasekhran PA, Radhan Rani G. A study on Factors Influencing the choice of Permanent Method of Family Planning. IOSR Journal of Dental and Medical Science. 2015;14(6):16-22.

16. International Center for Research on woman. Son preference and Daughter Neglect in India. Available from http://www.icrw.org/publications/sonpreference-and-daughter - neglect-india

17. Singh A, Ogollah R, Faujdar R, Saseendran Pallikadavath. Sterilization Regret among Married Women in India: Implication for the Indian national Family Planning Program International Prospective on Sexual and Reproductive Health 2012;38(4):18795 .

Cite this article as: Nagapurkar SN, Santpure AS, Giri PA, Bhanap PL. Study of biosocial factors affecting laparoscopic tubal ligation in rural Maharashtra, India. Int J Reprod Contracept Obstet Gynecol 2016;5:4461-5. 